\title{
The Analysis of the Effects of External Institutional Pressure and Internal Institutional Factors on the Quality of Accounting Information
}

\author{
Dwi Winarni $^{1}$, Rhis Ogie Dewandaru ${ }^{2}$, Bima Cinintya Pratama ${ }^{3}$, Maulida Nurul \\ Innayah $^{4}$, Prita Esita ${ }^{5}$ \\ dwiwinarni45@gmail.com ${ }^{1}$
}

Faculty of Economic and Business, Universitas Muhammadiyah Purwokerto, Indonesia ${ }^{12345}$

\begin{abstract}
This study aims to provide evidence that the Analysis of the Effects of External Institutional Pressure and Internal Institutional Factors on the Quality of Accounting Information. External institutional pressure in this study uses coercive isomorphism pressure, namely formal pressure that can be sourced from stakeholders and regulations. For internal institutional factors use the dimensions of management commitment and human resources. And for the quality of accounting information using four indicators namely relevant, reliable, comparable and understandable. This research uses quantitative methods with survey methods using questionnaires. The analytical tool used in this study is Partial Least Square (PLS) to test hypotheses. The population used is the Sleman Regional Government and the research sample is the entire Regional Work Unit (SKPD) in the Sleman Regional Government. The sampling method used was purposive sampling with the criteria of the Head of Finance and Secretary of the SKPD due to having sufficient responsibility and experience and was involved in the process of making accounting information or financial reports. The results showed strong evidence of the influence of external pressures on institutional internal factors. This finding concludes that external pressure is a driving factor in enhancing the capability of HR in the OPD, namely by the existence of new regulations and systems, training is conducted to improve performance and improve the latest capabilities in accordance with applicable regulations. A strong influence is also found on institutional internal factors that have a positive effect on the quality of accounting information. The existence of technology in the form of a computerized and integrated system makes it easy for employees to do accounting processing. For external pressures have a positive effect on the quality of accounting information, it shows that external pressures are one of the driving factors for improving or improving the quality of accounting information. External pressures such as the presence of regulations and stakeholders. The latter finding is that institutional internal factors mediate the influence of external pressures on the quality of accounting information. External institutional pressures in the mechanism of coercive and normative isomorphism, among others, pressure from regulation can shape the attitudes and behavior of actors and organizational structures towards the use of accounting information.
\end{abstract}

Keywords: External Institutional Pressure, Internal Institutional Factors, Quality of Accounting Information

\section{Introduction}

The implementation of New Public Management (NPM) in Indonesia not only occurred in the Central Government, but also occurred in the Local Government. NPM is a reform effort 
undertaken by the government including the development of performance measurement systems, involvement in Public-Private Partnerships (PPP) and changes in government accounting by applying accrual-based accounting in the public sector [1]-[3]. The change from cash-based accounting to accrual-based accounting is one of the factors to improve the quality of accounting information. In preparing LKPD 2015 (Laporan Keuangan Pemerintah Daerah/ Financial Statement Report in Local Govenment), all local governments are expected to have applied accrual-based accounting as the implementation of Government Regulation Number 71 of 2010 concerning Government Accounting Standards/ Standar akuntansi Pemerintah (SAP). Accrual-based accounting system is an important component that can support the realization of the quality of accounting information. The National Medium-Term Development Plan / Rencana Pembangunan Jangka Menengah Nasional (RPJMN) 2015-2019 that for 2016, the target number of local governments to apply accrual-based accounting is 22 provinces and 275 districts / cities. Government Regulation Number 71 of 2010, also discussed qualitative characteristics of accounting information that is, relevant, reliable, comparable, and understandable. The qualitative characteristics of accounting information is that it can affect the quality of financial statements so that the information in them can be quality.

Accounting reforms carried out in the Central Government and in the Local Government can respond to requests for accountability, transparency, and the use of information from the public sector submitted by many users. In addition, it aims to contribute to efficiency in decision making by providing useful accounting information, facilitating decision making in the public sector [4]. Reform of the government accounting system can ultimately succeed or fail, but the process has become a phenomenon to modernize the public sector. Thus, these reforms can develop under limited institutional capacity with weak human resources, low levels of accountability, deficiencies in the regulatory system, administrative inefficiencies and inadequate resources [5]. The quality of human resources is very important in implementing accounting information systems. Therefore, the characteristics of human resources who have education and experience tend to provide information based on relevant knowledge [6], [7]. [8] That internal institutional factors influence accounting information derived from the quality of human resources and management commitment. Thus, in addition to external pressures there are other factors that can affect the quality of accounting information.

[9] The research examined using the institutional theory of coercive isomorphism in local government organizations. The research focuses on isomorphic external pressures and indicators of external pressures, among others, from regulations and stakeholders. The research used a single case study of local e-government adoption and implementation in Jembrana regency in the Bali province. [10]) The research found that external pressures significantly affected the quality of accounting information in four large organizations in Australia, the study used case study method. External pressures also affect the quality of accounting information in Small and Medium Enterprises (SMEs) in Uganda, Ordinary Least Squares (OLS) was used to determine literacy levels and external user pressure affect the quality of accounting information controlling for firm size, accounting qualification and firm age [11]. Furthermore, [12] that external pressures can be the main driver for improving the quality of accounting information However, [13] that external pressures can affect the ability of government levels to be lower, especially those related to the implementation of a policy or procedure.

Based on the results of previous studies, the motivation of this study is to examine how external institutional pressures can affect institutional internal factors to produce quality 
accounting information. This study includes internal institutional factor variables as mediating variables between institutional external pressures and the quality of accounting information. This research used the institutional theory of coercive and normative isomorphism, because the theory can explain the phenomenon in practice in the environment of public sector organizations. The choice of institutional theory of isomorphism is based on the fact that the process of making and using accounting information cannot be separated from the social and institutional environment of local government [14]-[16]. The research method used is a quantitative method with a survey research design using a questionnaire. This design was used for the fact that it is feasible when a researcher wants to cover a large amount of opinions from different people about the same issues or topics. The analytical tool used in this study is Partial Least Square (PLS) because it has complex combinations and models and can use a relatively small sample size, to anticipate the lack of response rates from samples in the intended local government [17].

The local government was chosen as the object of research because it has characteristics in the current application of NPM. Local governments are given policies by the central government to implement NPM reforms and the adoption of techniques in the public sector, especially accounting reforms in developing countries [18]-[20]. The regional government which is the object of research is Sleman Regency, one of the regions that has succeeded in obtaining WTP opinion. The BPK RI Audit Report (LHP) for 2017 shows that the Sleman Regency LKPD received WTP opinion for five years in a row. Considerations in providing opinions on financial statements include compliance with Government Accounting Standards, adequacy of disclosure, compliance with laws and regulations, and the effectiveness of the internal control system [21]. This success shows that, Sleman District Government has a commitment in improving the quality of information including compliance with government financial management in Indonesia.

The local government of Sleman has recorded that up to 2017 it has received a WTP opinion from the BPK five times in a row. Despite the WTP's opinion, based on BPK's findings on the examination of the financial reports of the Sleman Regency Government, there are still some notes. The BPK found irregularities in the provision of housing development assistance for underprivileged communities through the Sleman Public Works and Housing Agency/Dinas Pekerjaan Umum dan Perumahan (PUP). BPK assessed that the assistance for 53 recipients was not on target. The reason was that the determination of recipients was not based on Regent Regulation No 4/2010 concerning Stimulant Assistance for the Community for Physical Development Activities [22]. The local government of sleman has also received notes from the BPK due to delays in financial reports from KONI, this has caused the decline in the WTP opinion achievement in 2011 and became an obstacle to achieving WTP in 2012 [22]. Furthermore, in 2017 the BPK found inadequate management of regional property/ Barang Milik Daerah (BMD) such as inventory management and fixed asset management [23]. \{Bibliography\} Thus, a more in-depth examination is needed with regard to the quality of accounting information in the Sleman district government.

[8]The study contribute to NIS by establishing the way coercive and normative external institutional pressures shape internal organisational environment and individual actors characteristics towards the use of accounting information in budgetary decision-making processes. [9]The study was carried out at one local government and only focuses on external institutional pressures, the findings may lack generalizability. However, in-depth study of the case phenomenon and the results can potentially contribute valuable theoretical and practical knowledge to the community. This research is expected to contribute practically, empirically and theoretically. The practical contribution of this research is that research findings can be 
used by regulators or policy makers, stakeholders can provide more positive pressure which can lead to positive changes in local governments to affect the quality of accounting information.

\subsection{Literature Review}

[24]The concept of institutional isomorphism is a useful tool for understanding politics and procedures in modern organizations. The concept of isomorphism consists of two types namely, competitive isomorphism and institutional isomorphism. Competitive isomorphism is related to competition to get consumers, while institutional isomorphism is related to the struggle for legitimacy or political power. This study uses institutional isomorphism because in the public sector especially government there is no competition as in competitive isomorphism. The adoption of legitimate elements leads to isomorphism with the institutional environment, so that organizational behavior or decisions taken by the organization can be influenced by institutions outside the organization [25].

[24]Identified three mechanisms of isomorphism, namely coercive, mimetic and normative isomorphisms. First, coercive isomorphism refers to the process by which organizations adopt certain features (traits) because of coercion (pressure) from the state, other organizations or society. Pressure on the organization can be formal or informal. Examples of coercive isomorphism include pressure from the central government or donors, namely as the donor. This pressure can be felt as a strength, persuasion or invitation to join an agreement. Coercive isomorphism tends to form artificial obedience or just ritual because motivation only follows the rules. Second, normative isomorphism is related to the process of change that comes from professionalization. Professionalization is a joint effort made by members of an organization to determine the conditions and methods of their work through a rationale and legitimacy in their work. For example, regional governments in a country adopted a new method because they realized that the method could be useful for them. The development of professionalization through two ways, namely education and legitimacy based on cognitive and professional development and elaboration that forms a new model. Third, mimetic isomorphism occurs because of imitation. This happens when an organization experiences uncertainty about carrying out a method. In this situation an organization will emulate other organizations by way of benchmarking, comparative studies or using the services of consultants. Institutional theory also shows that organizations follow legitimacy by adjusting isomorphic pressures in their environment [26]. In addition, organizations also respond strategically to organizational pressure [24], [27]. This study uses coercive and normative isomorphism because it fits the research context, namely external pressure and institutional internal factors caused by the existence of both types of isomorphism.

\subsection{External Pressure}

[24]The external pressure is a coercive pressure or force that forces an organization to adopt certain policies or to change the structure of its organization. Coercive pressure has significantly influenced the adoption and application of innovations in public organizations [28], [29]. Factors related to external pressures include coercive isomorphism institutional pressures. This pressure results from formal and informal pressures exerted by other organizations, due to the dependence on resources such as the financial and cultural aspects of the society in which the organization functions [24]. 
Some accounting information systems research explains that external pressures as a coercive force stem from many factors such as parent organizations and regulations [9], [30], [31]. Coercive isomorphism pressure is formal pressure that can be sourced from stakeholders and regulations. [13]The research explain that stakeholders include executives, the public, and other relevant agencies. Stakeholder involvement is an important component in the accounting and reporting process to ensure that the results of the accounting and reporting process are relevant to stakeholders and reflect the main issues, aspirations, and interests [32]. The efforts of government organizations to be transparent can also be done by making changes in daily practices. For example, it must disclose organizational performance procedures to the public and other stakeholders to be transparent [33].

The second coercive isomorphism pressure is regulation from the central government. The central government can enact laws and regulations that will affect local governments [34]. Regulation is an institutional element that regulates behavior and regulates interactions (Geels, 2004). In the context of government organizations, regulations or regulations are explicitly and formally applied to compile the structure of government institutions to behave in certain ways [9]. [35] emphasizes that regulation is all about rewards and punishment supported by sanctions. Likewise, local government institutions are encouraged by regulations to implement certain initiatives or policies such as the application of accounting information systems, in the context of improving the quality of accounting information. [34] found that public organizations obey formal or legal authority to always operate in a political context. In practice regulation can weaken or strengthen, thus that when policies are formulated, implementation is not necessarily appropriate [36]. This study uses regulations and stakeholders as factors that influence the quality of accounting information in local governments from external pressures.

\subsection{Institutional Internal Factors}

Coercive and normative isomorphism can be described through variables that can affect the quality of accounting information, namely management commitment and human resources. [8] The contingency theory suggests several main variables that can influence the use of accounting information in budgeting decisions including management commitment and human resources. Other contingency factors are part of human resources such as the accounting environment as a professional field, which has implications for the processing of accounting information. Leadership commitment as an organizational factor that influences the use of performance information in accounting [37]-[39]. Organizations have a great opportunity if they have a strong commitment in the organization[40].

\subsection{Quality of Accounting Information}

Accounting information can be defined economically or technically, and in social, political and institutional terms. Economically, accounting information is defined as a means of measuring, and communicating economic events [14]. Furthermore, [14] defines accounting information as a process for identifying, measuring and communicating economic information that enables information users to make the right decision. Accounting information can be made using a cash-based accounting reporting system and / or accrual-based accounting [18]. In Government Regulation No. 71 of 2010 it is explained that in order to improve the quality of accountability for government performance, the government must use accrual-based accounting, including regional governments. As stated in the Minister of Domestic Affairs 
Regulation Number 64 of 2013 which is a guideline for regional governments in carrying out full accrual-based accounting which has been carried out since 2015 .

[41] The relevant accounting information can be distinguished in decision making. If it does not affect the decision, then the information is said to be irrelevant to the decision taken. Relevant information will help users make predictions about the final results of past, present, and future events. Based on Government Regulation Number 71 of 2010, the qualitative characteristics of accounting information are: relevant, reliable, comparable and understandable. These characteristics are as normative requirements so that the quality of government financial reports is in accordance with what is intended. First, it is relevant, that is, if the information contained in it can influence users' decisions by helping them evaluate past events on the present, and predict the future, and confirm or correct their evaluation results in the past. Second, reliable, if the financial statement information is free from misleading notions and material errors, honestly presents every fact, and can be verified. Third, it can be compared, that is, if the information contained in the financial statements will be more useful if it can be compared with the financial statements of the previous period or the financial statements of the previous period or the financial statements of other reporting entities in general. Fourth, it can be understood if the government financial statement information is said to be understood if the user understands the information presented and is able to interpret it.

\subsection{External Pressure and Institutional Internal Factors}

This study uses institutional external pressures derived from coercive isomorphism. Coercive isomorphism pressures can originate from factors originating from formal and informal pressures, such as the dependence of financial resources [24]. [8]The influence of external pressures on internal institutional, in his research using contingency theory and institutional theory with internal institutions including a culture of transparency, internal regulations, computerized and budgeting systems, internal audit units and the availability and decentralization of quality accountants together with the application of quality accrual based accounting. These factors also experience changes due to the influence of factors related to external institutional factors [8]. [27]explains that internal institutional factors and organizational contingencies can be made shaped by coercive and normative pressures. Like, Government Regulation Number 71 of 2010 concerning Government Accounting Standards (SAP). The amendment is to improve the quality of accountability for government performance, namely the use of accrual-based accounting by the government, including regional governments. [9]) The external power of the central government (donors) and regulations influenced local governments to adopt and implement systems to improve administrative and service performance. Pressure from external organizations with coercive and normative isomorphism can affect the environment within the organization's internal. The hypothesis formulation in this study is:

H1: External pressure has a positive effect on institutional internal factors.

\subsection{Internal Institutional Factors and Quality of Accounting Information}

[24] Suggest that there are three types of institutional pressures that cause organizations to adopt new rules or practices, including coercive and normative isomorphism. Furthermore, management commitment is an organizational factor that influences the use of performance information in accounting information [37]-[39]. Meanwhile, institutional internal factors that influence accounting information can come from the quality of human resources and 
management commitment [8]. [8] found a positive influence of institutional factors on the use of accounting information and internal institutional factors can come from the quality of human resources and management commitment. These findings are supported by previous studies relating to human resource competencies [42], [43]. Therefore, based on the theory and results of previous research on the internal effects of institutional and accounting information, the hypothesis formulation in this study is:

$\mathrm{H} 2$ : Institutional internal factors have a positive effect on the quality of accounting information.

\subsection{External Pressure and Quality of Accounting Information}

[10]The external factors significantly influence the quality of accounting information, that is, with change management skills, organizations can use external pressure to accelerate the management of internal information quality. [11] The external pressure influences the quality of accounting information in Small and Medium Enterprises (SMEs) in Uganda. [8]The role of external institutional pressure with normative and coercive isomorphism in changing the internal institutional structure of the use of accounting information in budget decision making. The results show significant external institutional role pressure. [12] conclude the external pressures can be the main driver for improving the quality of accounting information. [8]The research in line with the perspective of NIS (New Institutional sociology), as a branch of institutional theory that external institutional pressures in normative and coercive mechanisms such as pressure from regulations can shape the attitudes and behavior of actors and organizational structures towards the use of accounting information in local government authorities or local governments. This is very likely to occur if there is an influence on the adoption and application of NPM accounting techniques accompanied by financial legitimacy and demands for efficiency by stakeholders and regulations to internal institutions.

Therefore, internal institutional factors namely human resources and stakeholders can mediate the influence of external institutional pressures on the quality of accounting information. Because the characteristics of human resources who have education and experience tend to provide information in a way based on extensive knowledge [6]. Thus, the hypothesis formulation in this study is:

H3: External pressure has a positive effect on the quality of accounting information.

H4: Internal institutional factors mediate the influence of external pressures on the quality of accounting information.

\section{Method}

Data collection uses a quantitative method approach and is carried out with a survey method using a questionnaire. The analytical tool used in this study is Partial Least Square (PLS) to test hypotheses. PLS is one of the variant-based SEM statistical methods designed to solve multiple regressions when specific problems occur in data, such as small sample sizes, missing data, and multicollinearity[17]. In addition, PLS is a variance-based structural equation analysis (SEM) which can simultaneously conduct measurement model testing as well as structural model testing. These characteristics make PLS very appropriate for this study, because it has complex combinations and models and can use a relatively small sample size, because to anticipate the lack of response rates from the sample in the intended local government. 
The population used is the Sleman Regional Government and the research sample is the entire Regional Work Unit (SKPD) in the Sleman Regional Government. The sampling method used was purposive sampling with the criteria of the Head of Finance and Secretary of the SKPD due to having sufficient responsibility and experience and was involved in the process of making accounting information or financial reports.

The steps of testing using PLS include, designing the Structural Model (Inner Model), Evaluation of Structural Model (Inner Model), Designing Measurement Model (Outer Model) and Construction of Diagram Pathways, Evaluation of Measurement Models (Outer Model), Validity Test, Test Reliability and hypothesis testing.

\section{Variable Measurement}

This study uses external pressure and institutional internal factors as independent variables. Institutional internal factors and the quality of accounting information as the dependent variable and institutional internal factors as the mediating variables.

Institutional external pressure that is caused by pressure from outside the organization in this case the pressure caused from outside the local government. Local governments in Indonesia are required to comply with regulations issued by the central government. In addition, it can be in the form of pressure from stakeholders, namely the executive, the community, and other relevant agencies, [13]. Research instruments adapt research [13]. Institutional External Pressure is divided into two dimensions, namely regulation and stakeholders. Regulation is measured by the issuance of laws and regulations. Stakeholders are measured by the Executive, Community and NGOs.

Institutional internal pressure factors are factors originating from internal organizations within the local government environment. This study uses dimensions of management commitment and human resources. Management commitment is organizational integrity in realizing quality of accounting information. [44]The integrity strategy is broader, deeper and requires not only a compliance with laws and regulations and can be realized if management has a strong commitment. Human resources, namely the ability possessed by employees who carry out their duties in realizing quality information. Indicators of management commitment are leadership, executive support, legislative support [34]. Whereas human resources use indicators, training, skills, involvement of experts / consultants, experience [45].

The quality of accounting information, using four indicators taken from Government Regulation Number 71 of 2010. These indicators are: First, relevant, that is, relevant information has the benefit of feedback, has predictive, timely and complete benefits. Second, reliable, honest presentation, verifiable and neutrality. Third, it can be compared, namely the comparison can be done internally and externally. Fourth, it can be understood that the user is assumed to have sufficient knowledge of the activities and operating environment of the reporting entity, as well as the user's willingness to learn the information in question.

\section{Result And Discussion}

\subsection{Research Instrument Trial Results}

A pilot study is conducted before the research questionnaire is sent to the actual respondents. Respondents used were 34 students who work in the public sector, especially government and are currently studying at the Master of Management (MM) Faculty of 
Economics and Business, Universitas Gadjah Mada. The characteristics of these respondents were chosen because they have characteristics similar to those of respondents who would be the target of the actual research sample.

The analysis used to test the trial data using PLS software, the results of the trial can be seen from the value of the construct validity and reliability of the research instruments. The loading factor value of the items used to measure the research construct has met the minimum loading standard $\geq 0.70$, but the loading factor which has a value $<0,70$ is still maintained, this is due to the need to repair ambiguous sentences in the questionnaire so that it causes less can be understood by respondents.

In addition, the reliability test results show that the instrument used is reliable, this can be seen from the value of the reliability of composites and alpha's alpha above 0.60 . Overall, the results of trials on this instrument are suitable for use in research.

\subsection{Overview of Respondents}

Data was collected by distributing research questionnaires to each SKPD in the Regional Government of Sleman. The distribution of questionnaires was carried out starting on April 23, 2018 and the deadline for collecting completed questionnaires was May 5, 2018. The number of samples that could be used in the study was $88.54 \%$ and the questionnaires that did not return were $11.46 \%$. Most respondents were berusia 50 years old at $44.70 \%$. The highest level of education was $44.70 \%$ of SI graduates and accounting education was $12.94 \%$ of SKPD secretary positions of $49.41 \%$ and $50.58 \%$. The data can be used as a support for the analysis of research results regarding the factor of institutional pressure in influencing the quality of accounting information.

\subsection{Data analysis}

The process of analyzing data using PLS is carried out with several analysis procedures, as follows:

1. Designing Structural Models

In the structural model, there are three constructs consisting of two exogenous (independent) constructs and one endogenous (dependent) construct. Structural model design is used to show the causality relationship between latent variables that have been built based on the substance of the theory [17].

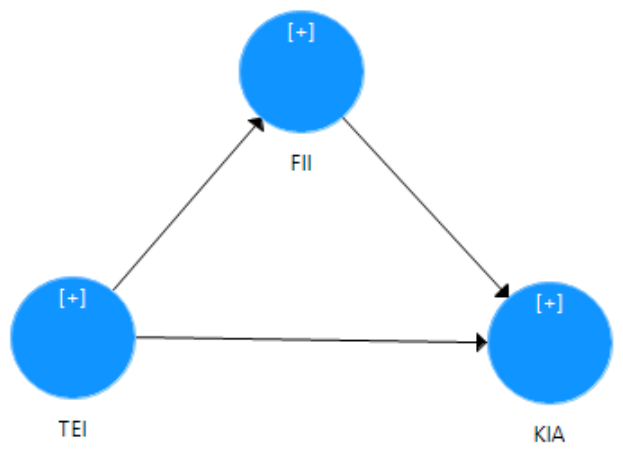

Fig.1. Structural Model 
2. Designing a Measurement Model

The measurement model is designed by linking the indicator block with its latent variables[17]. The measurement model for path analysis is shown in Figure 4.2 below:

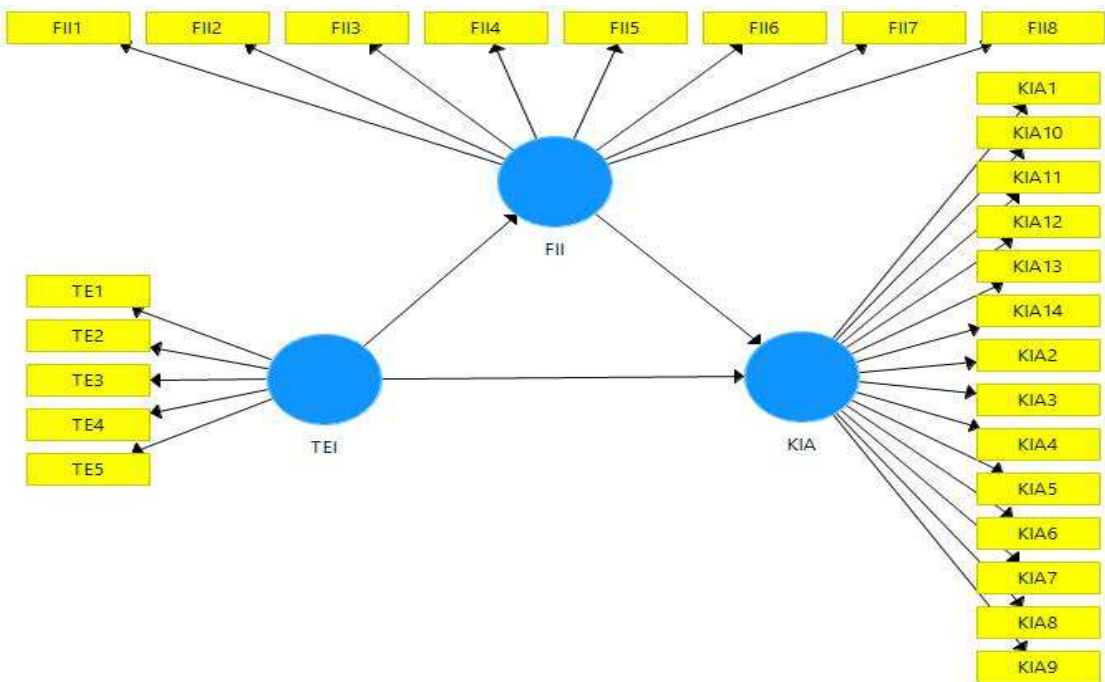

Fig.2. Measurement Model (Path Diagram)

3. Evaluation of the Measurement Model

[17]The parameter to assess the measurement model was convergent validity, discriminant validity obtained through logarithmic iteration. Figure 4.3 below is the path diagram of the PLS iteration analysis iteration analysis:

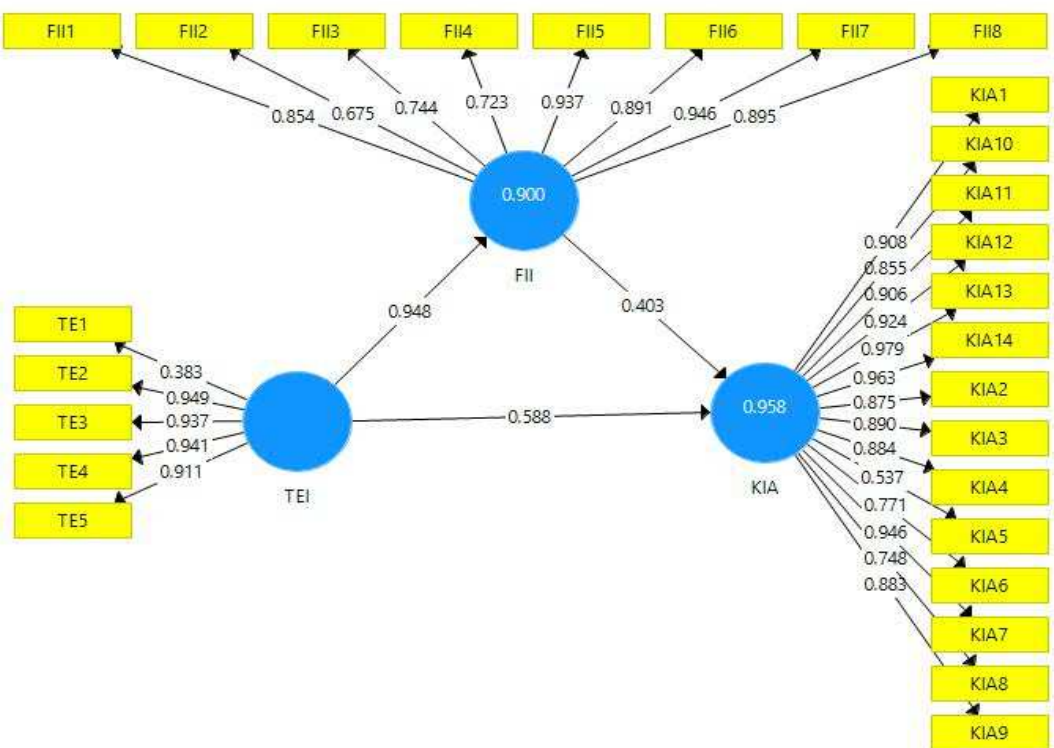

Fig.3. Path Analysis Diagram (PLS Alogarithm Iteration) 
Figure 4.3 shows that the results of the path analysis for each construct have a validity value of $\geq 0.7$ except for indicators TE1, FII2 and KIA5 so that the indicators are dropped. Then the test was carried out again without including the indicators TE1, FII2 and KIA5. The following results of the path analysis after dropping:

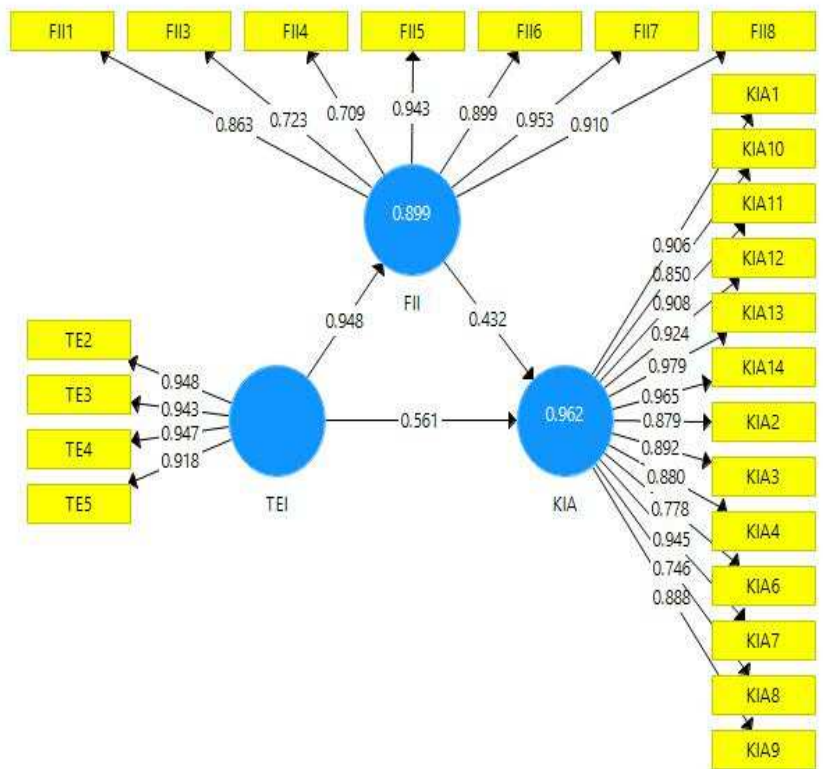

Fig.4. Path Analysis Diagram (PLS Iteration Algorithm) After Dropping

The summary below presents the results of the measurement model analysis (path analysis) using the PLS algorithm iteration:

Tabel 1. Overview Iterasi Alogaritma PLS

\begin{tabular}{lllll}
\hline \multirow{2}{*}{ Keterangan } & \multicolumn{2}{l}{ Uji Validitas } & Uji Reliabilitas & \multirow{2}{*}{ R Square* } \\
& AVE & Communality & Composite Reliability & \\
\hline TEI & 0,744 & 0,743 & 0,953 & \\
FII & 0,792 & 0,792 & 0,980 & 0,899 \\
KIA & 0,882 & 0,882 & 0,968 & 0,968 \\
\hline
\end{tabular}

\section{a. Convergent Validity Test}

Convergent validity test parameters can be seen from the AVE score and communality. The score of each variable is above 0.5 . This means that the probability of an indicator in a construct entering another variable is lower (less than 0.5 ). So that the probability of these indicators converge and enter the construct in question is greater that is above 0.5 or $50 \%$. From table 4.3 it can be seen that the highest AVE score in the $\mathrm{MCH}$ construct and the lowest in the $\mathrm{MCH}$ score while the highest communality score is in the $\mathrm{MCH}$ construct and the lowest in the TEI construct.

b. Discriminant Validity Test

Discriminant validity test parameters seen in the cross loading score is skor 0.7 . The score of each variable is $\geq 0.7$, meaning that each indicator in a construct in the measurement model has met the requirements of discriminant validity because each indicator in one construct is different from indicators in other constructs. 


\section{c. Reliability Test}

Reliability test can be seen from the composite reliability and Cronbach's alpha scores with the condition that the value is $\geq 0.7$. From the Composite Reliability score, all constructs have a value of $\geq 0.7$. The Cronbachs alpha score also has a value of $\geq 0.7$. Thus, the research constructs are declared reliable and then hypothesis testing can be performed. From table 4.3 it can be seen that the highest composite reliability score in the FII construct and the lowest score in the TEI construct. Thus, the construct of research is declared reliable. In general it can be stated that the research instrument is valid because it meets the criteria of convergent and discriminant validity and is reliable (reliable), so it is feasible to use for hypothesis testing.

4. Evaluation of Structural Models

The structural model is evaluated using R Square for the dependent construct. From table 4.3 it can be seen that the R Square value for the FII construct is 0.899 and the MCH construct is 0.698 . The result of this value means that the proposed research model can explain the construct variable of institutional internal factors of $89.9 \%$ and the rest is explained by other variables outside the proposed model. While the construct of the quality of accounting information is $69.8 \%$ and the rest is explained by other variables outside the proposed model. The higher the value of R Square, the better the prediction model of the research model being addressed.

\subsection{Hypothesis Test}

To test the hypotheses that have been proposed, structural testing models are carried out using the bootstraping function on PLS. Figure 4.4. The following presents the results of the structural model evaluation:

Table 2. Path coefficients (Path Coefficients; Mean, STDEV, T-Values)

\begin{tabular}{llllll}
\hline & $\begin{array}{l}\text { Original } \\
\text { Sample (O) }\end{array}$ & $\begin{array}{l}\text { Sample } \\
\text { Mean }(\mathbf{M})\end{array}$ & $\begin{array}{l}\text { Standard Error } \\
(\text { STERR) }\end{array}$ & $\begin{array}{l}\text { T Statistics } \\
(\mid \mathbf{O} / \text { STERR) }\end{array}$ & P Values \\
\hline FII -> KIA & 0,432 & 0,428 & 0,088 & 4,893 & 0,000 \\
$\begin{array}{l}\text { TEI -> FII } \\
\text { TEI -> }\end{array}$ & 0,948 & 0,949 & 0,013 & 75,687 & 0,000 \\
KIA & 0,561 & 0,566 & 0,085 & 6,575 & 0,000 \\
\hline
\end{tabular}

This research has 4 (four) hypotheses proposed. Hypothesis testing using PLS analysis can be seen in the table above. Analysis of the test results are:

Hypothesis 1: External pressure has a positive effect on institutional internal factors.

From the path coefficient table it can be seen that the influence of institutional external pressure on institutional internal factors is shown by the T-Statistics value of 75.687 that meets the requirements of $\geq 1.64$ (T-table), and the path coefficient value of 0.948 . Thus, H1 in this study was empirically supported (accepted).

H2: Institutional internal factors have a positive effect on the quality of accounting information.

From the path coefficient table it can be seen that the influence of institutional internal factors on the quality of accounting information is shown by the T-Statistics value of 4.893 which meets the requirements of $\geq 1.64$ (T-table), and the path coefficient value of 0.432 . Thus, $\mathrm{H} 2$ in this study was empirically supported (accepted).

H3: External pressure has a positive effect on the quality of accounting information. 
From the path coefficient table it can be seen that the influence of institutional pressure on the quality of accounting information is shown by the T-Statistics value of 6.575 which meets the requirements of $\geq 1.64$ (T-table), and the path coefficient value of 0.651 . Thus, $\mathrm{H} 3$ in this study is supported empirically (accepted).

Table 3. Path coefficients (Path Coefficients; Mean, STDEV, T-Values) indirect effect.

\begin{tabular}{llllll}
\hline & $\begin{array}{l}\text { Original } \\
\text { Sample (O) }\end{array}$ & $\begin{array}{l}\text { Sample } \\
\text { Mean (M) }\end{array}$ & $\begin{array}{l}\text { Standard Error } \\
\text { (STERR) }\end{array}$ & $\begin{array}{l}\text { T Statistics } \\
(\mid \text { O/STERR|) }\end{array}$ & P Values \\
\hline TEI -> KIA & 0,410 & 0,406 & 0,082 & 4,971 & 0,000 \\
\hline
\end{tabular}

\section{H4: Internal institutional factors mediate the influence of external pressures on the quality of accounting information.}

From the path coefficient table it can be seen that the influence of institutional internal factors mediating the influence of institutional external pressures on the quality of accounting information is shown by the T-Statistics value of 4.971 that meets the requirements of $\geq 1.64$ (T-table), and the path coefficient value of 0.410 . With de thus, H4 in this study was empirically supported (accepted).

Table. 4. Summary of Hypothesis Testing Results

\begin{tabular}{llllll}
\hline Hipotesis & Hubungan & Tanda & Koefisien & T-Statistics & Hasil \\
\hline H1 & TEI -> FII & Positif & 0,948 & 75,687 & Terdukung \\
H2 & FII -> KIA & Positif & 0,432 & 4,893 & Terdukung \\
H3 & TEI -> KIA & Positif & 0,561 & 6,575 & Terdukung \\
H4 & TEI -> KIA & Positif & 0,410 & 4,971 & Terdukung \\
\hline
\end{tabular}

The results of the quantitative data analysis show several important findings. Based on the findings of quantitative data analysis conducted with PLS found all supported hypotheses namely $\mathrm{H} 1, \mathrm{H} 2, \mathrm{H} 3, \mathrm{H} 4$. All four hypotheses have a strong level of significance with a $\mathrm{P}$ value of 0,000 which is below 0.05 . The results of the analysis in this study found evidence that external pressures had a positive effect on institutional internal factors. This finding is consistent with previous research which found that external pressures had a positive effect on institutional internal factors [8]. [9] found that external forces derived from legal, community, business, and central government factors could encourage the adoption and application of services to improve performance. In addition, the existence of new regulations and systems also requires training of $\mathrm{HR}$ in the OPD.

The second finding shows that institutional internal factors have a positive effect on the quality of accounting information. This is consistent with findings[37]-[39] which explain that management's commitment influences accounting information. [8] also found that internal institutional factors on the use of accounting information. This is supported by findings that are related to human resource competencies [42], [46]. The third finding shows that external pressures have a positive effect on the quality of accounting information. This is supported by previous research that external factors can influence the quality of accounting information with management skills in using external pressures to accelerate the management of internal information quality [10]. [8] found the role of external institutional pressure with normative and coercive isomorphism. [12] also concluded that external pressures can be the main driver for improving the quality of accounting information. The fourth research finding shows that institutional internal factors mediate the influence of external pressures on the quality of accounting information. [8] explains that new institutional sociology, as a branch of 
institutional theory that is external institutional pressure in coercive and normative mechanisms such as pressure from regulation can shape the attitudes and behavior of actors and organizational structures towards the use of accounting information.

\section{Conclusion}

This study is an empirical study to provide evidence of the Analysis of the Effects of External Institutional Pressure and Internal Institutional Factors on the Quality of Accounting Information. In addition, this study developed a model using the PLS approach in testing the proposed hypothesis. The results showed strong evidence of the influence of external pressures on institutional internal factors. External pressure is one of the factors of institutional pressure that can encourage the performance and capability of HR in the organization for the better. This finding concludes that external pressure is a driving factor in enhancing the capability of HR in the OPD, namely by the existence of new regulations and systems, training is conducted to improve performance and improve the latest capabilities in accordance with applicable regulations. A strong influence is also found on institutional internal factors that have a positive effect on the quality of accounting information. Internal institutional factors include things that can improve performance and originate from internal organizations such as; training, management commitment, technology, education and all businesses related to improving the capability of human resources. The existence of technology in the form of a computerized and integrated system makes it easy for employees to do accounting processing. Although the level of education is still taken into account, training is also a very important part of HR in accounting because only 12.94 percent of the survey results are derived from accounting education backgrounds. So training becomes a solution to improve and equalize accounting knowledge. Furthermore, management commitment becomes a very important part for internal organizations to realize quality information because management plays a role in change, implementation and decision making. The next finding is that external pressure positively influences the quality of accounting information, it shows that external pressure is one of the driving factors for improving or improving the quality of accounting information. External pressure can come from the presence of both coercive and normative isomorphism. Like the rules or regulations, demands from various stakeholders. The latter finding is that institutional internal factors mediate the influence of external pressures on the quality of accounting information. External institutional pressures in the coercive and normative isomorphism mechanism, among others, pressure from regulations can shape the attitudes and behavior of actors and organizational structures towards the use of accounting information, such as demands to follow new accounting rules, so that internal organizations organize training in an effort to fulfill and comply with these rules. Management is committed to encouraging its human resources to comply with regulations and perform to produce quality information. This research also found that the Sleman Regional Government has several things in realizing quality information. There are obstacles accounting staff aged $\geq 50$ years have lower performance compared to younger employees. Different educational backgrounds are not a significant obstacle because training is carried out so that they have the same knowledge and abilities.

Theoretically this research has implications about the findings of the factor of institutional pressure in influencing the quality of accounting information. Coercive and normative institutional isomorphisms are also part of the factors that influence the quality of accounting 
information. This study uses institutional isomorphism as part of institutional theory. The theory is widely used to explain phenomena and provide a complex view in the environment of public sector organizations. In addition, the use of institutional isomorphism theory is also based on the phenomenon that the management of accounting information cannot be separated from the institutional environment. The findings of this study broaden the results of previous studies and add to the literature in the field of public sector accounting.

The practical implications of this research are useful for public sector organizations (executive) or policy makers (legislative). The practice implications include:

1.External institutional pressure in encouraging the realization of the quality of accounting information is an important part of management in the organization. So that management is able to take advantage of pressure as a driving factor in improving the quality of information through improving human resource capabilities, especially accounting and technology employees. Accounting staff must also be prepared to face changes caused by external pressures such as changes in regulations, technology and accounting information systems used.

2. Institutional internal factors such as management's commitment to change management are also very necessary in the face of external pressures. So as to be able to encourage human resources working in the field of accounting are able to produce good performance in realizing quality information. Likewise with the component of increasing the ability of human resources such as training, it must be utilized to the maximum, considering that not all accounting employees have an educational background from accounting.

3. For policy makers, it is necessary to make regulations that are part of external institutional pressure. In order to encourage quality accounting information so that it can have an impact on effective and efficient financial management.

This study has limitations on research method because it focuses on one local government, it would be better if you use a mixed method. So that the research results can be studied more deeply. Suggestions for further research can dig deeper into management strategies and expand the scope of variable use by adding information usage variables. Thus it can be tested the extent to which management strategies in the face of institutional pressure and the use of quality and useful information both for economic and social interests.

\section{References}

[1] J. Broadbent and J. Guthrie, Public sector to public services: 20 years of "contextual" accounting research, vol. 21, no. 2. 2008.

[2] A. F. Gaspar and T. A. Mkasiwa, "The Use of Performance Information by Local Government Stakeholders in Tanzania," vol. 2, no. 3, pp. 51-63, 2014.

[3] A. Goddard, "Accounting and NPM in UK Local Government - Contributions Towards Governance and Accountability," Financ. Account. Manag., vol. 21, no. 2, pp. 191-218, 2005.

[4] M. I. B. Alijarde, "The Usefulness of Financial Reporting in Spanish Local Governments," Financ. Account. Manag., vol. 13, no. 1, pp. 17-34, 1997.

[5] G. J. van H. and S. T. Ni Putu S.H. Mimba, "Public sector performance measurement in developing countries A literature review and research agenda," 2007.

[6] R. Vyas and A. L. Souchon, "Symbolic use of export information," Int. Mark. Rev., vol. 20, no. 1, pp. 67-94, 2003.

[7] L. Zhou, "The Research on Issue and Countermeasures of Accounting Information of SMES," Int. J. Bus. Manag., vol. 5, no. 3, pp. 223-225, 2010.

[8] L. Mbelwa, "Factors Influencing The Use Of Accounting Information In Tanzanian Local 
Government Authorities (LGAS): An Institutional Theory Approach,” Public Sect. Accounting, Account. Audit. Emerg. Econ., vol. 15, pp. 143-177, 2015.

[9] N. Nurdin, R. Stockdale, and H. Scheepers, "The influence of external institutional pressures on local e-government adoption and implementation: A coercive perspective within an indonesian local e-government context," Lect. Notes Comput. Sci. (including Subser. Lect. Notes Artif. Intell. Lect. Notes Bioinformatics), vol. 7443 LNCS, pp. 13-26, 2012.

[10] H. Xu, J. Horn, N. G. Daryl, N. Binshan, H. Xu, and G. D. Nord, "Key issues of accounting information quality management : Australian case studies Key issues of accounting information quality management : Australian case studies," 2012.

[11] I. Nalukenge, S. K. Nkundabanyanga, and V. Tauringana, Literacy, external user-pressure and quality of accounting information of Ugandan SMEs, vol. 12, no. PARTA. Emerald Group Publishing Ltd., 2012.

[12] E. Edvardsson and E. Enquist, Quality improvement in governmental services: The role of change pressure exerted by the "market," vol. 18, no. 1. 2006.

[13] P. Frumkin and J. Galaskiewicz, "Institutional Isomorphism and Public Sector Organizations," vol. 14, no. 3, pp. 283-307, 2004.

[14] P. M. Collier, "THE POWER OF ACCOUNTING : A FIELD STUDY OF LOCAL FINANCIAL MANAGEMENT IN A POLICE FORCE by RP9937 December 1999 This paper describes the introduction of local financial management into a police force, can reinforce the interpretive scheme and satisfy bot," Business, no. 0121, pp. 1-34, 1999.

[15] S. Modell, "Performance measurement and institutional processes: A study of managerial responses to public sector reform," Manag. Account. Res., vol. 12, no. 4, pp. 437-464, 2001.

[16] B. N. Potter, "Accounting as a social and institutional practice: Perspectives to enrich our understanding of accounting change," Abacus, vol. 41, no. 3, pp. 265-289, 2005.

[17] W. Abdillah and J. Hartono, Alternatif Structural Equation Modeling (SEM) Dalam Penelitian Bisnis. 2015.

[18] P. Adhikari and F. Mellemvik, "The rise and fall of accruals: a case of Nepalese central government," J. Account. Emerg. Econ., vol. 1, no. 2, pp. 123-143, 2011.

[19] A. E. Sarker, "New public management in developing countries: An analysis of success and failure with particular reference to Singapore and Bangladesh," Int. J. Public Sect. Manag., vol. 19, no. 2, pp. 180-203, 2006.

[20] C. Alawattage, T. Hopper, D. Wickramasinghe, and R. I. C. Tambulasi, "Who is fooling who?: New public management-oriented management accounting and political control in the Malawi's local governance," J. Account. Organ. Chang., vol. 3, no. 3, pp. 302-328, 2007.

[21] "Sleman Raih WTP Lima Tahun Berturut-Turut," 2015. .

[22] BPK Yogyakarta, "WTP Akan Sulit Terealisasi.," 2013. .

[23] BPK Yogyakarta, "Pemberian Bantuan Tak Tepat Sasaran," 2018.

[24] P. DiMaggio and W. Powell, "The Iron Cage Revisited : Institutional Isomorphism and Collective Rationality in Organizational Fields Author ( s ): Paul J . DiMaggio and Walter W. Powell Source: American Sociological Review, Vol . 48 , No . 2 ( Apr ., 1983 ), pp . 147-160 Published," Am. Sociol. Rev., vol. 48, no. 2, pp. 147-160, 1983.

[25] L. G. Zucker, "The Role of Institutionalization in Cultural Persistence Author ( s ): Lynne G . Zucker Source: American Sociological Review, Vol . 42, No . 5 , ( Oct ., 1977), pp . 726-743 Published by : American Sociological Association Stable URL : http://www.jsto," Zucker, vol. 42, no. 5, pp. 726-743, 1977.

[26] R. Ashworth, G. Boyne, and R. Delbridge, "Escape from the iron cage? Organizational change and isomorphic pressures in the public sector," J. Public Adm. Res. Theory, vol. 19, no. 1, pp. 165-187, 2007.

[27] R. Suddaby, "Challenges for institutional theory," J. Manag. Inq., vol. 19, no. 1, pp. 14-20, 2010.

[28] E. PR, Berke. J, Dixon. N, "Coercive and cooperative intergovernmental mandates : a comparative analysis of Florida and New Zealand environmental plans,” vol. 24, pp. 451-468, 1997. 
[29] C. Cho and D. S. Wright, "Managing Carrots and Sticks : Changes in State Administrators, Perceptions of Cooperative and Coercive Federalism During the 1990s," vol. 2, no. Spring, 2001.

[30] N. S. Huigang Liang, Qing Hu, "Assimilation of Enterprise Systems : The Effect of Institutional Pressures and the research a rticle a ssimilation of e nterprise s ystems : t he e ffect of $i$ nstitutional $p$ ressures and the m ediating," no. March, 2007.

[31] I. B. H. H. Teo, K. K. Wei, "predictingin tentiont o adopt interorganizationlailn kages: an institutionaple rspectif," vol. 27, no. 1, pp. 19-49, 2013.

[32] R. Olesson, E., Albert, E., Coroneos, R., Leeson, R., and Wyatt, "Options for a Local Government Framework Government Framework," Options, no. January, 2012.

[33] J. C. Bertot, P. T. Jaeger, and J. M. Grimes, "Using ICTs to create a culture of transparency: Egovernment and social media as openness and anti-corruption tools for societies," Gov. Inf. Q., vol. 27, no. 3, pp. 264-271, 2010.

[34] R. Akbar, R. Pilcher, and B. Perrin, Performance measurement in Indonesia: the case of local government, vol. 24, no. 3. 2012.

[35] F. W. Geels, "From sectoral systems of innovation to socio-technical systems Insights about dynamics and change from sociology and institutional theory," vol. 33, pp. 897-920, 2004.

[36] P. D. L. Julnes and M. Holzer, "Promoting the Utilization of Performance Measures in Public Organizations : An Empirical Study of Factors Affecting Adoption and Implementation," no. December 2002, 2018.

[37] M. Dull, "Results-model reform leadership: Questions of credible commitment," J. Public Adm. Res. Theory, vol. 19, no. 2, pp. 255-284, 2009.

[38] D. P. Moynihan and P. W. Ingraham, "Integrative leadership in the public sector: A model of performance-information use," Adm. Soc., vol. 36, no. 4, pp. 427-453, 2004.

[39] D. P. Moynihan and S. K. Pandey, "The big question for performance management: Why do managers use performance information?," J. Public Adm. Res. Theory, vol. 20, no. 4, pp. 849$866,2010$.

[40] A. J. Morgan and S. A. Inks, “Technology and the,” vol. 472, pp. 463-472, 2001.

[41] D. Kieso, T. D. Warfield, and J. J. Weygandt, Intermediate Accounting. 2011.

[42] J. Taipaleenmäki and S. Ikäheimo, "International Journal of Accounting On the convergence of management accounting and fi nancial accounting - the role of information technology in accounting change," Int. J. Account. Inf. Syst., 2013.

[43] J. Askim, "How do politicians use performance information? An analysis of the Norwegian local government experience," Int. Rev. Adm. Sci., vol. 73, no. 3, pp. 453-472, 2007.

[44] S. Paine and S. Paine, "Managing for Organizational Integrity Managing for Organizational Integrity."

[45] K. S. Cavalluzzo and C. D. Ittner, "Implementing performance measurement innovations : evidence from government," vol. 29, pp. 243-267, 2004.

[46] J. Askim, "The Demand Side of Performance Measurement : Explaining Councillors ' Utilization of Performance Information in Policymaking," no. December 2014, pp. 37-41, 2009. 